\title{
E-LEARNING APPLICATION IN MUSICAL EDUCATION: NEEDS AND POSSIBILITIES
}

\author{
Zrinka Šimunović, University of Slavonski Brod, EDUDpt, Croatia
}

\section{Introduction}

Technological progress, or in other words, the digital revolution, a name that more clearly describes the speed and manner in which this process takes place, is changing our world in multiple areas and across multiple levels. Due to the complexity and the organization of the formal education system, the implementation and the use of technological resources does not take place sufficiently and at the same speed in all schools. The entry of technology into teaching depends on the users' capabilities and technical resources, i.e. on each individual teacher and the technological equipment at his disposal (Nart, 2016). And while the offer of digital tools for creating, performing and sharing music has become widely available and financially acceptable to the general population, which according to Savage (2007) has accelerated the process of technological change in music, the usage of technology in schools with traditional music practice is very rare (Mills \& Murray, 2000). The availability of ICT resources in music schools, such as technological equipment and licensed computer programs designed to assist learning and teaching in the users' mother tongue (especially those intended for music education), the lack of teachers' competencies required to use technology in teaching, as well as the absence of methodological frameworks that could support planning and executing of such lessons are the main reasons for this delay of technology implementation in the music education system. According to a 2018 study by the Organization for Economic Co-operation and Development (OECD), more than $60 \%$ of teachers said that they did not feel ready to use digital technology in teaching. By contrast, in a public consultation launched by the European Commission in 2021 on the new Digital Education Action Plan (2021-2027), over $60 \%$ of teachers stated that they had improved their digital skills and that the crisis caused by COVID-19 forced them to use technology more than usual. In the near future, it is realistic to expect that ICT will be integrated into the usual music teaching curriculum (Crow, 2005). Teachers should advance from being the passive users of digital tools to becoming the digital innovators capable of using technology to improve their teaching skills and consequently achieving greater success with learning outcomes (Koehler \& Mishra, 2005). 


\section{E-Learning Application in Musical Education: Needs and Possibilities}

But how much is technology changing us as music teachers? How much is our teaching changing? And formal music education in general? What is good about this change and what is not good for our students? We are discussing and emphasizing the benefits that technology provides in music teaching, however, certain special demands, that such education requires, technology cannot fulfil yet. For instance, demonstrating proper body posture, along with correct arm and hand position, avoiding injuries while performing music (Waddell \& Williamon, 2019) or delivering online teaching at a high artistic level (Adileh, 2012). These are all actions that, in addition to multidimensional activities, presuppose a "live" teacher (Ruismäki \& Juvonen, 2009), a "live" model observed and followed by the students with more of their senses than just sight and hearing. Through the method of interviews with music school teachers, we will try to find answers to the questions posed here and some additional ones. The aim of this paper is to encourage the scientists and teachers in music education to think about and find the best solutions for optimal and purposeful use of new technological achievements.

\section{Methodology}

The conducted research is qualitative in nature. The obtained data were processed by classical content analysis (Leech \& Onwuegbuzie, 2008) including the induction process (Creswell, 1994). In qualitative research, such a process involves multiple reading of the obtained data in order to get sufficient knowledge of the researched material. The data are then coded in the first- and second-level codes, which are again categorized and grouped according to the correlation between the research data and the theories.

\section{Participants}

The process of selecting participants for this study comprised of the non-probability sampling method, i.e. convenience sampling. The condition for selecting the teachers who participated in the research was that at the time of the research they were employed in the same institution as the researcher herself. According to Lava and Kvale (1995; p.220) the criteria by which the researcher is part of the group being tested is one of the most important conditions that qualitative research should meet. The music school in which the research was conducted includes primary and secondary music education with an emphasis on one of the areas: instrumental, theoretical, singing and dance. When selecting teachers, one of the criteria was to have representatives in all of the listed areas of work and in both levels of music education. The convenient sample consisted of 8 teachers, four instrument teachers, two music theory teachers, one dance teacher and one voice teacher. Of these, two teachers work in secondary school, three teachers work in both primary and secondary school, and three teachers work only in primary school. The work experience of the participants ranges from 5 to 30 years. 


\section{E-Learning Application in Musical Education: Needs and Possibilities}

\section{Instruments}

Data were collected by a semi-structured interview guided by a flexible interview protocol and supplemented by follow-up questions and comments (adjusted according to Price, 2020, which, according to Ayres (2008), is suitable for research that requires a deeper analysis and personal experience of the participants). Questions covered areas such as participants' experiences while they were still students themselves and their encounters with technology in that process, participants' use of technology in their current role as teachers, their attitudes towards online teaching and the changes that it brings in curriculum planning and teaching performance, e.g.:

"During your student experience, what methods (briefly describe) and what technology (including video / audio devices) did your teachers use while teaching?"

"When did you start using technology in your teaching?"

"What role does technology play in your lesson planning?"

"What is the biggest change in your teaching methods over the last few months?"

"What are the limitations of online teaching?"

\section{Process}

Selected participants were offered the opportunity to take part in the research. The purpose and the importance of the research were presented. Participants were guaranteed anonymity and ethical data management. After the preliminary interviews, a recorded interview was conducted, after which the data were transcribed in the literal sense. The interview lasted approximately 30 minutes.

\section{Data analysis}

The obtained answers were coded and the first- and second-level codes were extrapolated. Figure 1 shows thematic categories that were labelled by summarizing the sentences with related meaning of the studied statements of the participants. The main topic is "E-learning in Music Education" which is divided into two categories named "Transformation of teaching" and "Technology in main role". The aforementioned categories were then divided into subcategories related to specific areas, which were determined using the method of extrapolating the most frequently used words in the participants' answers. 


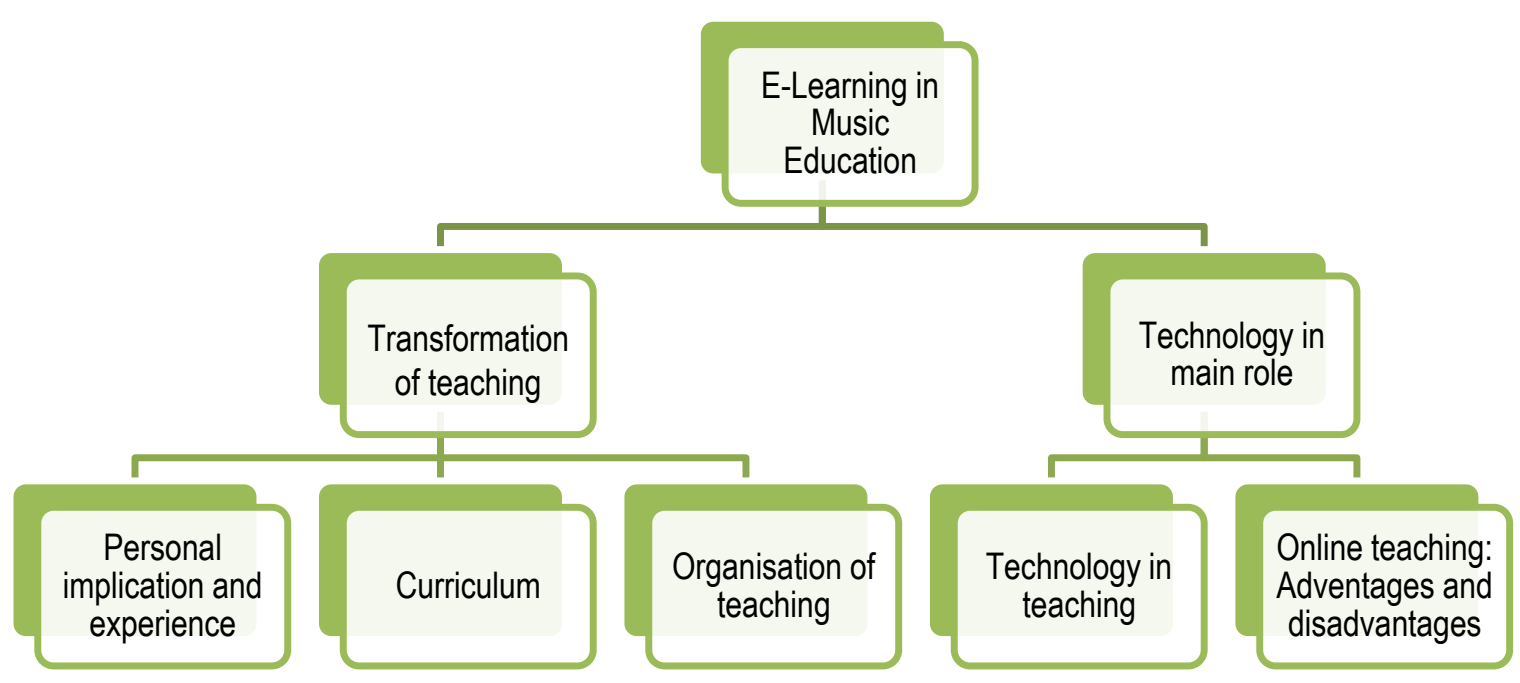

Figure 9. Category Analysis

\section{Results}

At this point, we are going to present the results of the study organized in the following six categories:

\section{Personal implication}

This category includes questions related to the teachers' previous experiences, while back when they were still students themselves. When asked about the motivation that prompted them to start teaching, some teachers $(\mathrm{N}=3)$ indicated teaching as their second choice that they were in a way constrained to choose because they didn't succeed as concert musicians due to life circumstances. Nevertheless, the other part of the participants $(\mathrm{N}=5)$ is devoted to both the teaching profession and the transfer of knowledge to young artists. One of them says:

"I've soon realized that some of the non-standard methods of teaching and explaining that I've been using (while trying to help my colleagues) proved as being highly effective and that most of 'my students' mastered the material very quickly and successfully.”

When asked how much and what type of technology in particular their teachers once used during the teaching process, participants answered according to expectations that technology was used to a much lesser extent in comparison to today. The most common answers regarding the specific devices were TV sets, video and audio devices, cassette tapes and compact discs, which were used to familiarize the students with the performances of famous musicians. 
Šimunović, Z.

E-Learning Application in Musical Education: Needs and Possibilities

\section{Curriculum}

The curriculum by which the participants were taught while they were students did not meet their needs at the time. Therefore, immediately after they started working as teachers themselves, they implemented their own curriculum, combining ideas gathered at permanent teacher's training courses with the use of technology. In addition to the increased use of technology in their teaching, when compared to their teachers in the past, participants also invest time in adapting teaching methods and strategies to the individual needs and abilities of each of their students, such as:

"I suggest my students record their playing and try to improve it by noticing the mistakes. To motivate them to rehearse, I advise my students to listen to the performances of certain musical compositions and specific performers. “

The participants unanimously agree that classroom teaching curriculum and online teaching curriculum differ greatly and that learning expectations and outcomes in online teaching are lower than in classroom teaching.

\section{Organisation of teaching}

Lesson planning for the three participants is the same in both classroom and online teaching. Three out of eight participants plan their lessons in the same way in both classroom and online teaching. However, the other five participants have stated some specific characteristics of online lesson planning: it is more extensive and detailed than preparing for classroom teaching, browsing the Internet for ideas is more common than in classroom teaching, giving up on the improvement of student's performance, and also completely omitting certain content that is otherwise easily performed in a regular classroom environment. Online lessons generally last the same as classroom lessons for all participants, except for one participant who organizes her online lessons in such a way that students send recordings of their performances, and then she analyses them and talks to students about them. Changes in the organization of teaching caused by online teaching are visible in the number of hours spent in front of a computer, the use of digital tools, but also some particularities such as:

"Insisting less on the perfect student's performance, and putting more emphasis on maintaining student's motivation.”

"Enabling students to work independently." 
Šimunović, Z.

E-Learning Application in Musical Education: Needs and Possibilities

\section{Technology in teaching}

Participants describe their first use of technology in teaching differently. Two participants first started using the technology during the last year (due to the pandemic), while the others have been using it since the very beginning of their teaching career. The participants themselves have most often found the motivation and ideas to start implementing technology in their teaching on the Internet, or through conversations with other colleagues, and somewhat less often from their university professors. In the preparation of teaching, technology plays an important role for most participants because it enables them to find sheet music, ideas, varied selection of compositions, it also helps improve the teaching process and facilitate communication with colleagues and students. One participant distinguishes the amount of technology used in the preparation of live classroom lessons where she practically does not use it at all compared to her online teaching, while another participant does not care much about technology in his lesson preparation. When asked how and whether technology has affected the changes in their teaching, the participants state that students have become more independent and conscientious in their work. The participants also have a better insight, because they are able to devote more time and analyse the technical part of playing skills when studying recordings that their students make and send. They also mention that they themselves, through technology, have advanced in the profession and improved their teaching. The smartphone is used for both private and teaching purposes by all participants. They believe that the exclusion of the smartphone would affect the delivery of online classes, which would not even be possible, the process of teaching and learning the content would slow down, and there would be a lack of creative ideas because there would be no exchange on the Internet. However, one participant claims the exact opposite:

"With the help of a smartphone, you acquire other people's ideas and knowledge, but when you are alone, you encourage your own creativity."

\section{Online teaching: Advantages and disadvantages}

How the participants see the benefits of online teaching, which has lately been the most commonly used way. The advantage of online teaching lies in the fact that it is the only possible way of teaching when the classroom teaching is not an option, so consequently it is the best possible choice. Students are more responsible and conscientious in their approach to work than in live classroom teaching, they are more independent. Teachers and students are protected from the virus infection. Everyone is becoming acquainted with the useful side of technology. Online teaching encourages students to self-evaluate more, which positively affects the learning outcomes. Disadvantages of online teaching differ in individual and group teaching. Participants who are instrumentalists most often mention the impossibility to directly influence the position of the hand, arm and body posture while 


\section{E-Learning Application in Musical Education: Needs and Possibilities}

their students are playing and also the impossibility of tuning musical instruments when teaching younger students:

"A student who fails to understand the required instructions in interpretation during an online lesson is deprived of the teacher's help inperson and thus fails to correct the wrong posture or find the correct tone."

For older students, the disadvantages of online teaching are related to the extent and quality of the program:

"Older students lack progress in their artistic expression and the completion of the music program, especially high school graduates."

All participants agree that online teaching has its limitations and that the lack of physical contact is irreplaceable in this type of teaching.

\section{Conclusion}

With this research, we tried to get teachers' answers to several key questions regarding the use of technology in music education. We have started from the theoretical frameworks in which the increase in the use of technology in education has been visible in the last few years, and especially in the last year due to the COVID-19 crisis (European Commission, 2021). Our participants, music educators, confirmed this fact by comparing their personal schooling, their prior teaching experience and the current situation. They all agree that today they are forced to use technology much more and in a much more complex way than they had the opportunity to see from their teachers or compared to how they used it themselves a year ago. The biggest change relates to the transition from in-person teaching to online teaching. Accordingly, the participants have noted increased effort necessary to adapt the curriculum as well as the teaching methods and strategies to the individual needs and abilities of each of their students. There are far more advantages of technology-assisted teaching and when used in a purposeful and planned manner, it significantly helps in achieving teaching objectives. Nevertheless, the participants agree, that without the knowledge and practical skills that music educators can provide to their students, music education cannot fulfil its purpose. In this sense, online teaching is a good temporary solution to which they have adapted, mostly on their own, or using the ideas of their colleagues that they found on the Internet. The results obtained by this research are insufficient for a more in-depth analysis of the use of technology in music education and they need to be extended with quantitative data. Digital Education Action Plan 2021-2027 (European Commission, 2021) predicts, among other things, the improvement of education that will be obtained by analysing the data and anticipating possible situations. This research, expanded by the increased number of participants along with the 


\section{E-Learning Application in Musical Education: Needs and Possibilities}

corresponding quantitative analysis, could serve for a clearer concept of music education in the near future.

\section{References}

Adileh, M. T. (2012). Teaching music as a University eclective course through e-learning. Australian Journal of Music Education, 1, 71-79. Retrieved from https://files.eric.ed.gov/fulltext/EJ1000246.pdf

Ayres, L. (2008). Semi-structured Interview. In L. M. Given (Ed.), The Sage encyclopedia of qualitative research methods (pp. 810-811). Los Angeles, London, New Delhi, Singapore: SAGE Publications.

European Commission (2021). Digital Education Action Plan (2021-2027).

Communication from the Commission to the European Parliament, the Council, the European Economic and Social Committee and the Committee of the Regions.

Retrieved from https://ec.europa.eu/education/education-in-the-eu/digital-educationaction-plan_en

Creswell, J. W. (1994). Research design - Qualitative and Quantitative Approaches. London - New Delhi: Sage Publictions. Thousand Oaks.

Crow, B. (2005). Music-related ICT in education. In C. Philpott (Ed.), Learning to Teach Music in the Secondary School: A Companion to School Experience (pp. 115-139). London: Rautledge Farmer.

Koehler, M. J., \& Mishra, P. (2005). What happens when teachers design educational technology? The development of technological pedagogical content knowledge. Journal of Educational Computing Research, 32(2), 131-152. doi:10.2190/0EW7-01WBBKHL-QDYV

Lave, J., \& Kvale, S. (1995). What is anthropological research? An interview with Jean Lave by Steinar Kvale. International Journal of Qualitative Studies in Education, 8(3), 219-228. doi:10.1080/0951839950080301

Leech, N. L., \& Onwuegbuzie, A. J. (2008). Qualitative data analysis: A compendium of techniques and a framework for selection for school psychology research and beyond. Psychological Association, 23(4), 587-604. doi:10.1037/1045-3830.23.4.587

Mills, J., \& Murray, A. (2000). Music technology inspected: good teaching in Key Stage 3, British Journal of Music Education, 17(2), 129-56. Retrieved from https://www.cambridge.org/core/journals/british-journal-of-musiceducation/article/music-technology-inspected-good-teaching-in-key-stage3/C5A96D8CB330B739DA59907E47544078 
Nart, S. (2016). Music software in the technology integrated music education. Turkish Online Journal of Educational Technology (TOJET), 15(2), 78-84. Retrieved from https://files.eric.ed.gov/fulltext/EJ1096456.pdf

OECD (2018). Development Co-operation Report 2018: Joining Forces to Leave No One Behind. Paris: OECD Publishing. doi:10.1787/dcr-2018-en.

Price Jr, D. F. (2020). Experience, Technology and Curriculum for Today's Online Instrumental Music Educator (Doctoral dissertation). Boston University, Boston. Retrieved from https://search.proquest.com/openview/7bb022ae95a07934f159b85547fcb25e/1?pqorigsite $=$ gscholar $\& \mathrm{cbl}=18750 \&$ diss $=$

Ruismäki, H., \& Juvonen, A. (2009). The new horizons for music technology in music education. The Changing Face of Music Education. Music and Environment, 98-104. Retrieved from https://www.swsu.ru/sbornikstatey/pdf/The_new_horizonts_for_music_technology.pdf

Savage, J. (2007). Reconstructing music education through ICT. Research in Education, 78(1), 65-77. Retrieved from https://www.researchgate.net/profile/Jonathan_Savage2/publication/233514091_Rec onstructing_Music_Education_through_ICT/links/556f0e9308aeab7772282a04/Reco nstructing-Music-Education-through-ICT.pdf

Waddell, G., \& Williamon, A. (2019). Technology use and attitudes in music learning. Frontiers in ICT, 6, 11. doi:10.3389/fict.2019.00011 